NBER WORKING PAPER SERIES

GLOBALIZATION OF THE ECONOMY

Jeffrey A. Frankel

Working Paper 7858

http://www.nber.org/papers/w7858

\author{
NATIONAL BUREAU OF ECONOMIC RESEARCH \\ 1050 Massachusetts Avenue \\ Cambridge, MA 02138 \\ August 2000
}

This paper was written to be a concise survey on globalization for a non-specialist audience. It is forthcoming in Governance in a Globalizing World, edited by Joseph Nye and John Donahue, Brookings Institution Press. The author would like to thank for comments Jagdish Bhagwati, Ash Carter, Farhad Rassekh, Dani Rodrik, Pierre Sauve, Ira Shapiro, Rob Stavins, Arvind Subramanian, Daniel Tarullo and Alan Winters; and to thank for research assistance Ha Yan Lee. The views expressed herein are those of the author and not necessarily those of the National Bureau of Economic Research.

(C) 2000 by Jeffrey A. Frankel. All rights reserved. Short sections of text, not to exceed two paragraphs, may be quoted without explicit permission provided that full credit, including (C) notice, is given to the source. 
Globalization of the Economy

Jeffrey A. Frankel

NBER Working Paper No. 7858

August 2000

JEL No. F0, F1

\begin{abstract}
Globalization of trade and finance has gone a long way over the last half-century. But it is less impressive than most non-economists think, judged either by the standard of 100 years ago or by the hypothetical standard of perfect international integration. The paper documents the extent of globalization, and some reasons for the barriers that remains. It then briefly considers the implications for economic growth and the implications for goals not measured by GDP - equality and the environment. The conclusion is that globalization is not the primary obstacle to efforts to address such concerns.
\end{abstract}

Jeffrey A. Frankel

Kennedy School of Government

Harvard University

79 JFK Street

Cambridge, MA 02138-5801

and NBER

jeffrey_frankel@harvard.edu 


\section{Globalization of the Economy}

Jeffrey Frankel

Economic globalization is one of the most powerful forces to have shaped the post-war world. In particular, international trade in goods and services has become increasingly important over the last 50 years, and international financial flows over the last 30 years. This chapter documents quantitatively the process of globalization with respect to trade and finance. It then briefly goes beyond the causes of international economic integration to consider its effects, concluding that globalization is overall a good thing, not just with respect to economic growth but also when non-economic goals are taken into account.

The two major drivers of economic globalization are reduced costs to transportation and communication in the private sector, and reduced policy barriers to trade and investment on the part of the public sector. Technological progress and innovation have long been driving the costs of transportation and communication steadily lower. In the post-war period we have seen major further cost-saving advances, even within ocean shipping: supertankers, roll-on-roll-off ships, and containerized cargo. Between 1920 and 1990 the average ocean freight and port charges per short ton of U.S. import and export cargo fell from $\$ 95$ to $\$ 29$ (in 1990 dollars). An increasing share of cargo goes by air. Between 1930 and 1990, average air transport revenue per passenger mile fell from $\$ 0.68$ to $\$ 0.11$. Jet air shipping and refrigeration have changed the status of goods that had previously been classified altogether as not tradable internationally. Now fresh-cut flowers, perishable 
broccoli and strawberries, live lobsters, and even ice cream are sent between continents. ${ }^{1}$ Communications costs have fallen even more rapidly. Over this period the cost of a 3minute telephone call from New York to London fell from $\$ 244.65$ to $\$ 3.32$. Recent inventions such as faxes and the internet require no touting.

It is easy to exaggerate the extent of globalization. Much excited discussion of the topic makes it sound as though the rapid increase in economic integration across national borders is unprecedented. Some commentators imply that it has now gone so far that it is complete; one hears that distance and national borders no longer matter, that the nation state and geography are themselves no longer relevant for economic purposes, that it is now as easy to do business with a customer across the globe as across town. After all, has not the worldwide web reduced cross-border barriers to zero?

It would be a mistake for either policy-makers or private citizens to base decisions on the notion that globalization is so new that the experience of the past is not relevant, or that the phenomenon is now irreversible, or that national monetary authorities are now powerless in the face of the global marketplace, or that the quality of life of Americans either its economic or non-economic aspects -- is determined more by developments abroad than by American actions at home.

It is best to recognize that at any point in history many powerful forces are working to drive countries apart, at the same time as other powerful forces are working to shrink the world. In the 1990s, for example, at the same time that forces such as the

${ }^{1}$ Sources are given in Chapter 3 of Frankel (1997). Krugman (1995) emphasizes that many of the most important technical advances occurred before 1870, such as steel-hulled ships, the screw propeller, and the trans-Atlantic telegraph. Cooper (1995) argues that the technological progress of this century has had more of an effect than Krugman admits, as do Bordo, Eichengreen and Irwin (1999). 
internet and dollarization have led some to proclaim the decline of the nation state, more new nations have been created (out of the ruins of the former Soviet bloc) than in any decade other than the decolonizing 1960s, each with its own currencies and trade policies. ${ }^{2}$ The forces of shrinkage have dominated in recent decades, but the centrifugal forces are important as well.

\section{Two Benchmarks for Measuring Economic Integration}

There are two respects in which the overall post-World War II record of economic integration across national borders, powerful as it has been, is not quite as striking as widely believed. The first perspective is to judge by the standard of 100 years ago. The second is to judge by the standard of what it would mean to have truly perfect global integration.

\section{Judging by the Standard of 1900}

The globalization that took place in the $19^{\text {th }}$ century was at least as impressive as the current episode. The most revolutionary breakthroughs in transportation and communication had already happened by 1900 -- for example, the railroad, steamship, telegraph, and refrigeration. Freight rates had fallen sharply throughout the century. An

\footnotetext{
${ }^{2}$ Alesina, Spolaore and Wacziarg (1999) argue that the correlation between trade integration (as reflected in trade/GDP ratios), and political separatism (as reflected in the number of countries in the world), is a systematic pattern historically, attributable to the need for economies of scale. If countries can attain these economies of scale through international trade in an open global system, they need not attain them through political
} 
environment of political stability was provided by the Pax Britannica, and an

environment of monetary stability was provided by the gold standard. O'Rourke and

Williamson (1999) show that, as a result of rapidly growing trade, international

differences in commodity prices narrowed dramatically. ${ }^{3}$

It is inescapable to invoke a particularly famous quote from Keynes (1920).

"What an extraordinary episode in the progress of man that age was which came to an end in August 1914!...The inhabitant of London could order by telephone, sipping his morning tea in bed, the various products of the whole earth...he could at the same time and by the same means adventure his wealth in the natural resources and new enterprise of any quarter of the world...."

The world took a giant step back from economic globalization during the period 1914-1944. Some of the causes of this retrogression were: isolationist sentiments in the West that followed the first World War, the monetary instability and economic depression that plagued the interwar period, increases in tariffs and other trade barriers including most saliently the adoption by the U.S. Congress of the Smoot-Hawley tariff of 1930, the rise of the fascist bloc in the 1930s, and the rise of the Communist bloc in the 1940s. All of these factors pertain to barriers that were created by governments, in contrast to the forces of technology and the private marketplace which tend to reduce barriers. As a result, the world that emerged in 1945 was far more fragmented economically than the world that had turned to war in 1914.

The victors, however, were determined not to repeat the mistakes they had made at the time of the first world war. This time, they would work to promote economic

union with other countries.

${ }^{3}$ But it is not always the case that "There is nothing new under the sun." Economic globalization in the $19^{\text {th }}$ century was qualitatively different from what had come in preceding centuries, e.g., in the Age of Exploration. O'Rourke and Williamson (1999) show that by the relevant economic criteria the "big bang" of globalization is properly 
integration, in large part to advance long-term political goals. To govern international money, investment, and trade, they established multilateral institutions - the International Monetary Fund, World Bank, and General Agreement on Tariffs and Trade. ${ }^{4}$ The United States initially led the way, by reducing trade barriers and making available goldconvertible dollars.

By one basic measure of trade, exports or imports of merchandise as a fraction of total output, it took more than 25 years after the end of World War II before the United States around 1970 reached the same level of globalization that it had experienced on the eve of World War I. This fraction continued to increase rapidly between 1971 and 1997 - reaching about $9 \%$ today, still far lower than that in Britain throughout the late $19^{\text {th }}$ and early 20th centuries. By other measures, some pertaining to the freedom of factor movements, the world even by the turn of the millennium was no more integrated than that of the preceding turn of the century. ${ }^{5}$

Most people find surprising that trade did not reattain its pre-World War I importance until the early 1970s. The significance of the comparison with 100 years ago goes well beyond factoids that economic historians enjoy springing on the uninitiated. Because technological know-how is irreversible - or was irreversible over the second millennium, if not entirely over the first - there is a tendency to see globalization as

dated in the $19^{\text {th }}$ century.

${ }^{4}$ The conference at Bretton Woods, New Hampshire, in 1944 had proposed the creation of an International Trade Organization as the third of the institutions, the one to promote free trade. In this aspect, however, the US Congress opted for a reprise of its rejection 25 years before of the President's League of Nations, dooming the ITO at conception. It was not until 1995 that the stop-gap GATT in Geneva became a true international multilateral agency, the World Trade Organization.

${ }^{5}$ Baldwin and Martin (1999) provide a cornucopia of data comparing postwar globalization with the earlier wave in 1820-1914. 
irreversible. But the political forces that fragmented the world for 30 years (1914-1944) were evidently far more powerful than the accretion of technological progress in transport that went on during that period. The lesson is that there is nothing inevitable about the process of globalization. For it to continue, world leaders must make choices of the sort made in the aftermath of World War II, instead of those made in the aftermath of World War I.

\section{Judging Globalization 2000 by the Standard of Perfect International Integration}

Perhaps perfect economic integration across national borders is a straw man. The reader is likely to think so by the end of this chapter, even if he or she did not think so at the beginning. But straw men have their purposes, and in this case ample rhetoric exists to justify the interest. A good straw man needs to be substantial enough to impress the crows, and yet not so substantial that he can't be knocked flat. On both scores the proposition of complete international integration qualifies admirably.

Consider again the basic statistics of trade integration, a country's total exports of goods and services, or total imports, as a fraction of GDP. With the rapid increase in services included, these ratios now average $12 \%$ for the United States. The current level of trade likely represents a doubling from 100 years ago. As remarkable as is this evidence of declining transportation costs, tariffs, and other barriers to trade, it is still very far from the condition that would prevail if these costs and barriers were zero. More sophisticated statistics below will document this claim. But a very simple calculation is sufficient to make the point. US output is about $1 / 4$ of gross world product. The output of producers in other countries is thus about $3 / 4$ of gross world product. If Americans were 
prone to buy goods and services from foreign producers as easily as from domestic producers, then foreign products would constitute a share of US spending equal to that of the spending of the average resident of the planet. The US import/GDP ratio would equal .75. The same would be true of the US export/GDP ratio. And yet these ratios are only about $1 / 6$ of this hypothetical level $(12 \% / 75 \%=1 / 6)$. In other words, globalization would have to increase another six-fold, as measured by the trade ratio, before it would literally be true that Americans did business as easily across the globe as across the country.

Other countries are also a long way from perfect openness in this sense. The overall ratio of merchandise trade to output worldwide is about twice the US ratio. This is to be expected, as other countries are smaller. For the other two large economies -Japan, and the EU considered as a whole -- the ratio is closer to the US level. In almost all cases, the ratio falls far short of the level that would prevail in a perfectly integrated world. ${ }^{6}$

In the chart, the vertical dimension represents the share of a country's output that is sold to its fellow citizens, rather than exported. The downward movement for most countries illustrates that they have become more open over the last 130 years. (One can also see that the integration trend was interrupted during the interwar period.) We are

\footnotetext{
${ }^{6}$ The average country constitutes about $1 / 2$ of one percent of world output. (There are about 180 members of the IMF.) Thus in a fully globalized world, the average country would buy or sell $991 / 2$ percent of its output abroad. Again, most economies fall far short of this degree of international integration. Singapore and Hong Kong are the only two exceptions. Their exports and imports are each more than $100 \%$ of GDP, which points up that the denominator of the ratio should really be a measure of gross sales, not a valueadded measure like GDP. In other words, the statistic that globalization must increase six-fold before it is complete, is an underestimate.
} 
still far from perfect openness: the share of output sold at home is disproportionate to the domestic market's weight in the world economy. Other countries, though smaller and therefore more open than the United States, are as from perfect openness.

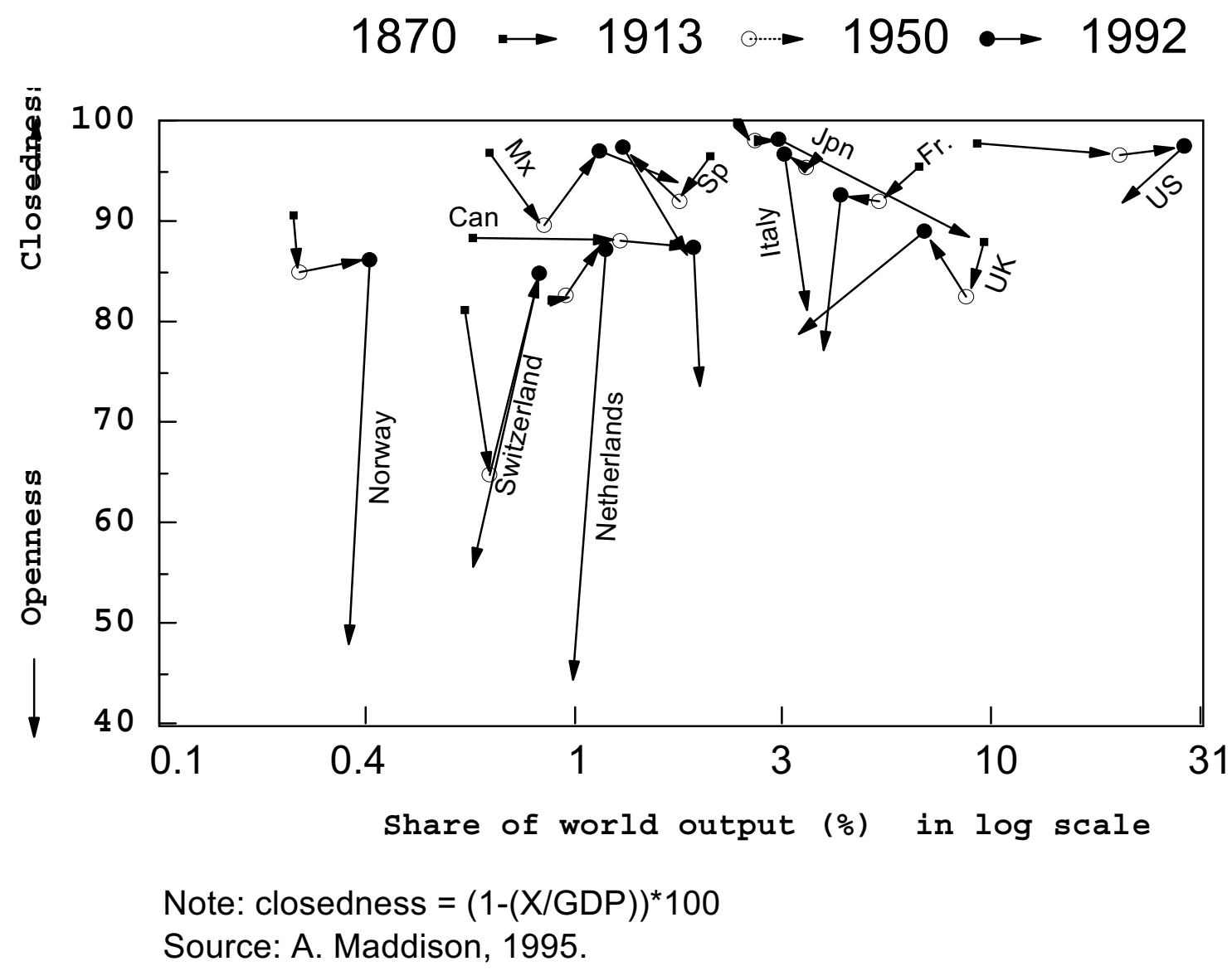

Why is globalization still so far from complete? To get an idea what is the combination of transportation costs, trade barriers, and other frictions that remains yet to be dismantled, we must delve more deeply into the statistics. 


\section{Statistical Measures of Economic Integration}

It can be instructive to look at direct measures of how some of the barriers to trans-border integration have changed during the 20th century -- the level of tariffs on manufactures as an illustration of trade policy, or the price of a trans-Atlantic telephone call as an illustration of technological change in communications and transportation. Nevertheless, the political and physical determinants are too numerous and varied to be aggregated into a few key statistics that are capable of measuring the overall extent of integration in trade or finance. Tariff rates, for example, differ tremendously across commodities, and there is no single sensible way to aggregate them. The situation is even worse for non-tariff barriers. Alternative possible measures of the importance of tariffs and other trade barriers have very low correlation with each other. ${ }^{7}$

A comprehensive measure of a shipping costs for a country's trade is the ratio of c.i.f. trade value (measured as the cost to the importing country, including insurance and freight) to f.a.s. or f.o.b. trade value (measured as it leaves the exporting country as "free alongside ship" or "free on board"). The margin for US trade fell from about $9 \frac{1 / 2}{2}$ percent in the 1950s to about 6 percent in the 1990s. (The average worldwide is under 4 percent.) But this probably understates the decline in shipping costs. The reason is that the composition of trade has changed, and c.i.f. margins vary widely across commodities and across trading partners. ${ }^{8}$

\footnotetext{
${ }^{7}$ Pritchett and Sethi (1994).

${ }^{8}$ Across commodities, the c.i.f. margin for U.S. trade ranges from a low of $0.7 \%$ for pearls and $0.8 \%$ for aircraft, to a high of $25.1 \%$ for salt, sulphur, earth, stone and plastering material. Across U.S. trading partners, the c.i.f. margin ranges from $1.7 \%$ for Mexico to $25.8 \%$ for Guinea. For an elaboration of these statistics, see pages $40-45$ of
} 
It is more rewarding to look at summary measures of the effects of cross-border barriers on the patterns of trade and investment, than to look at measures of the barriers themselves. Two sorts of measures are in use: those pertaining to quantities and those pertaining to prices.

Measures of quantities might appear more direct: "Just how big are international flows?" But economists often prefer to look at price measures. In the first place, the quality of the data is often higher for prices than quantities. (This is particularly true of data on international financial markets - the data on the prices of foreign securities are extremely good, the data on aggregate international trade in securities are extremely bad.) In the second place, even at a conceptual level, international differentials in the prices of specific goods or specific assets, which measure the ability of international arbitrage to hold these prices in line, are more useful indicators of the extent of integration in a causal sense. Consider the example of US trade in petroleum products. It is not especially large as a percentage of total US output or consumption of petroleum products. And yet arbitrage ties the price of oil within the United States closely to the price in the world market. Even a pair of countries that record no bilateral oil trade whatsoever will find that their prices move closely together. It is the absence of barriers and the potential for large-scale trade that keeps prices in line and makes the markets integrated in the most meaningful sense, not the magnitude of trade that takes place.

Frankel (1997). 


\section{The Ability of Arbitrage to Eliminate International Differentials in Goods Prices}

According to basic economic theory, arbitrage, defined as the activity of buying an item in a place where it is cheap and simultaneously selling the same item where it is expensive, should drive prices into equality. Its failure to do so perfectly is a source of repeated surprise to economists (though perhaps to nobody else !). Often the explanation is that the commodities in question are not in fact identical. Brand names matter, if for no other reason than matters of retailing, warranty, and customer service. A BMW is certainly not the same automobile as a Lexus, and even a BMW sold in Germany is not the same as a BMW sold in the United States (different air pollution control equipment, for example). When the comparison across countries uses aggregate price indices, as in standard tests of "Purchasing Power Parity", it is no surprise to find only weak evidence of arbitrage. ${ }^{9}$ The finding of international price differentials is more surprising in the case of non-differentiated non-brand-name commodities such as standardized ball bearings. Tests find that price differentials for specific goods are far larger across national borders than they are within countries. Exchange rate variability is a likely culprit. $^{10}$

Even more surprising is the paucity of evidence of a tendency for price differentials to diminish over the long sweep of history. Froot, Kim and Rogoff (1995) have obtained data on prices in England and Holland since the year 1273 for eight specific commodities (barley, butter, cheese, eggs, oats, peas, silver and wheat). Deviations from the so-called Law of One Price across the English Channel are no smaller or less persistent now than they were in past, even though technological progress has certainly reduced the cost

\footnotetext{
${ }^{9}$ The literature is surveyed by Rogoff (1996).
} 
of shipping these products dramatically. Evidently other forces have counteracted the fall in transport costs; candidates are trade barriers under Europe's Common Agricultural Policy, and volatility in the exchange rate between the guilder and the pound. ${ }^{11}$

\section{Factors Contributing to Home-Country Bias in Trade}

Geography in general -- and distance in particular -- remain far more important inhibitions to trade than widely believed.

Distance Distance is still an important barrier to trade, and not solely because of physical shipping costs. The effects of informational barriers are observed to decrease with proximity, and with linguistic, cultural, historical, and political links. We might call it social distance. Linnemann (1966) called it "psychic distance" and Drysdale-Garnaut (1982) named it "subjective resistance."

Among many possible proofs that distance is still important, one of the simplest is the observed tendency toward geographical agglomeration of industries. The tendency for industry to concentrate regionally is evidence both of costs to transportation and communication and of increasing returns to scale in production.

The agglomeration occurs even in sectors where physical transport costs are negligible, as in financial services or computer software. Financial firms concentrate in Manhattan and information technology firms concentrate in Silicon Valley. The reason they choose to locate near each other is not because they are trading physical commodities with

\footnotetext{
${ }^{10}$ For example, Engel (1993).

${ }^{11}$ Over the period 1870-1913, on the other hand, O'Rourke and Williamson (1999), find a steady downward trend in the differential in wheat prices between Europe and the United
} 
each other and wish to save on shipping costs. Rather, face-to-face contact is important for exchanging information and negotiating deals.

The importance of distance is also revealed by analysis of data on prices of goods in different locations. If transport costs and other costs to doing business at a distance are important, then arbitrage should do a better job of keeping prices of similar goods in line when they are sold at locations close together rather than far apart. Engel and Rogers (1996) study prices in 14 consumption categories for 23 Canadian and U.S. cities. They find that the distance between two North American cities significantly affects the variability of their relative prices.

Similar results emerge by looking at trade quantities rather than prices. The gravity model says that trade between a pair of countries is inversely related to the distance between them, and proportional to the product of their sizes, by analogy with Newton's law of gravitational attraction. It fits the data remarkably well, and is wellfounded in the theory of trade in goods that are imperfect substitutes. In part because data are so abundant (a set of 100 countries offers 100x99=9,900 pairs of export observations), standard errors tend to be small.

Statistical estimates find highly significant effects of distance on bilateral trade. When the distance between two countries is increased by one percent, trade between them falls by $0.7-1.0$ per cent. This statistic, like the others that follow, pertains to the effect in isolation, holding constant other effects on trade, such as the size of the trading partners. The wonderful property of Ordinary Least Squares regression analysis is that it is capable of examining the independent effect of one factor at a time. (The sources for

States as the result of trade. 
the gravity estimates cited here, unless otherwise specified, are Frankel, 1997, Rose, 2000, and Frankel and Rose, 2000. An early reference is Linnemann, 1966.)

Other geographical variables Other physical attributes of location also have statistically significant effects. Landlocked countries engage in less trade by a factor of about $1 / 3$, holding other factors equal. ${ }^{12}$ Two countries that are adjacent to each other trade about 80 percent more than two otherwise-similar countries.

Linguistic and colonial factors Linguistic barriers remain an impediment to trade. Two countries that speak the same language trade about 50 percent more than two otherwise-similar countries. The multitude of languages is one of the reasons why economic integration remains far from complete in the European Union.

Colonial links have also been important historically. In 1960, the year when the break-up of the largest colonial empires began in earnest, trade between colonies and the colonial power was on average 2 to 4 times greater than for otherwise similar pairs of countries. ${ }^{13}$ This effect, already reduced from an earlier peak in the colonial era, has continued to decline in the 1970s and 1980s. But it has not disappeared. Indeed, if small dependencies are included in the sample, then two units that share the same colonizer still trade on average an estimated $80 \%$ more with each other than two otherwise similar countries (as recently as 1990). In addition, if one of the pair is the colonial mother country, trade is 5 to 9 times greater than it would otherwise be. ${ }^{14}$

\footnotetext{
${ }^{12}$ Frankel and Romer (1999).

${ }^{13}$ Kleiman (1976).

${ }^{14}$ The colonial relationship is defined as of 1945. (Before taking the exponent, the
} 
Military factors The effects on bilateral trade of politico-military alliances, wars have also been examined. Theoretically and empirically (in the gravity framework) trade is generally higher among countries that are allies, and lower among countries that are actual or potential adversaries. Understandably, if two countries are currently at war, there is usually a negative effect on trade. It runs as high as a 99 per cent reduction in 1965. More typical is an 82 percent reduction in $1990 .{ }^{15}$

Free Trade Areas Regional trading arrangements reduce tariffs and other trade barriers within a group of countries, though there is a range from mild Preferential Trading Arrangements to full-fledged Economic Unions. Often the members of such groups are already tightly linked through proximity, common language, or other ties. But even holding constant for such factors, in the gravity model, the formation of a Free Trade Area is estimated on average to raise trade by 70 to 170 percent. ${ }^{16}$ A serious common market, such as the European Union, can have a bigger effect. Nevertheless, in each of the EU member countries, a large bias toward trade within that country remains. Nitsch (1997) finds that intra-national trade remains about seven times as high as international trade with an EU partner country of similar size and distance.

Political links A naïve economists' view would be that once tariffs and other explicit trade barriers between countries are removed, and geographic determinants of

estimate is 1.75 in 1990 , or 2.2 for $1970-90$ pooled.)

${ }^{15}$ Mansfield (1993), Mansfield and Bronson (1997), and Gowa and Mansfield (1993).

${ }^{16}$ Frankel, 1997; Rose, p.25. 
transportation costs are held constant, trade should move as easily across national boundaries as within them. But this is far from the case in reality. If two geographic units belong to the same political union, such as France and its overseas departements, trade is roughly tripled. Thus political relationships among geographic units have larger effects on trade than such factors as explicit trade policies or linguistic barriers.

Common country Even after adjusting for distance (including non-contiguity) and linguistic barriers, all countries still exhibit a substantial bias toward buying domestic goods rather than foreign. Wei (1996) estimates this bias for OECD countries; it has declined only very slowly over time and is still statistically significant (though the United States has the smallest bias of all).

There would be some great advantages of having data at the level of states or provinces within countries. We would be able to ascertain how trade between two geographical entities is affected by their common membership in a political union. We have learned that when two geographical units share such links as speaking a common language, their bilateral trade is clearly boosted. It stands to reason that when two units share a common cultural heritage or legal system, their trade will be enhanced by even more. Data are not generally available on trade among U.S. states, Japanese prefectures, German lander, British counties, or French departments. But there do exist data on trade undertaken by Canadian provinces, among each other and with major American states. They show a strong intra-national bias to trade. Ontario exports three times as much to British Columbia as to California, even though the latter has ten times as many people. (The figures are for 1988.) 
McCallum (1995) applied the gravity model to trade among the provinces and states. The usual effects of size and distance show up. The fascinating result is the effect of a dummy variable to represent when two states or provinces lie in the same country. Two such provinces trade about twenty times as much with each other as would a province and a state that are otherwise similar but lie on opposite sides of the border. Helliwell (1998) has updated this test to reflect data under the Canada-US Free Trade Agreement. He finds that the intra-Canadian bias factor was still about 12 for 1993-96, down from 17 in 1988.

The result is reminiscent of the striking finding, in the paper "How Wide is the Border?" by Engel and Rogers, that crossing the Canadian-U.S. border adds more to the relative price variability between two cities than does traversing a physical distance of 2500 miles within either country. This tendency for Canadian provinces to trade with one another is all the more surprising because they tend to maintain trade barriers against one another, never having had the advantage of a Constitution like the one in the United States that reserves trade policy exclusively for the federal level. Reasons for the intra-Canadian bias in trade include the ease of doing business within the same legal system, an integrated media and advertising sector, nationwide store chains, and an East-West railroad network. Helliwell and McCallum (1995) "suspect that the answers lie in a whole host of educational and geographic ties based on migration and family ties and supported by networks of transportation, communication and education, along with portability of health care and pension rights -- if not completely of beer." Presumably the sources of intra-national bias are even stronger for other countries that do not share the cultural proximity and liberalized trade relations of Canada and the United States. 


\section{Currencies}

There has long been reason to suspect that the existence of different currencies, and especially the large fluctuation in the exchange rates between currencies since the break-up of the Bretton Woods monetary system in 1971, has been a barrier to international trade and investment. Exchange rate fluctuations are clearly related to the failures of the law of one price observed in goods markets. When it is observed that, for example, Canadians and Americans trade far more with their countrymen than with each other, in a context where trade barriers, geography and linguistic barriers have been eliminated, the currency difference is one of the prime suspects. Until recently, however, it has been difficult to find strong evidence that currency factors discourage trade and investment. The gravity model has now been used for this purpose. ${ }^{17}$ It turns out that eliminating one standard deviation in exchange rate variability -- e.g., from its mean of $7 \%$ to zero -- raises trade between a pair of countries by an estimated 13 percent. Furthermore, Rose has found that going all the way and literally adopting a common currency has a much bigger effect; it multiplies trade by an additional 3.5 times.

Promoting trade and finance is one of several motivations for the recent adoption of common currencies or currency boards by roughly twenty countries over the last decade (including the 11 members of European Economic and Monetary Union in 1999). At the same time, however, approximately the same number of new currencies have come into existence, as a result of the breakup of the former Soviet bloc.

\footnotetext{
${ }^{17}$ Frankel (1997, 135-139), Frankel and Wei (1997) and Rose (1999).
} 


\section{Measures of Financial Market Integration}

The delegates who met at Bretton Woods in 1944 had a design for the world monetary system that explicitly did not accord financial markets the presumption that was accorded trade in goods, the presumption that international integration was unambiguously good and that barriers should be liberalized as rapidly as possible. Although economic theory can make as elegant a case in favor of free trade in assets as for free trade in goods and services, the delegates had been persuaded by the experience of the 1930s that some degree of controls on international capital movements was desirable. It was not until the final 1973 break-down of the system of fixed exchange rates that Germany and the United States removed their capital controls. Japan and the United Kingdom kept theirs until the end of the 1970s, and most other European countries did not liberalize until the end of the 1980s. Many emerging-market countries also opened up to large-scale international capital movements in the 1990s (though the subsequent crises have convinced some observers that those delegates at Bretton Woods might have had it right in the first place).

Analogously to the statistical findings regarding international integration of goods markets, tests regarding financial markets show international integration that has increased tremendously over the last 30 years, but that is less complete than often supposed. This generalization applies to quantity-based tests as well as to price-based tests.

It is true that the gross volume of cross-border capital flows has grown very large. Perhaps the most impressive and widely-cited statistic is the gross volume of turnover in foreign exchange markets: $\$ 1.5$ trillion per day worldwide, by April 1998, which is on 
the order of a hundred times greater than the volume of trade in goods and services. Net capital flows are for most purposes more interesting than gross flows, however. Net capital flows today are far smaller as a share of GDP than were pre-WWI net flows out of Great Britain and into such land-abundant countries as Argentina, Australia, and Canada. ${ }^{18}$ Furthermore, Feldstein and Horioka (1980) argued in a very influential paper that net capital flows are far smaller than one would expect them to be in a world of perfect international capital mobility: a country that suffers a shortfall in national saving tends to experience an almost-commensurate fall in investment, rather than making up the difference by borrowing from abroad. ${ }^{19}$ Similarly, investors in every country hold far lower proportions of their portfolios in the form of other countries' securities than they would in a well-diversified portfolio, a puzzle known as home country bias. ${ }^{20}$ Evidently, imperfect information and transactions costs are still important barriers to cross-country investment.

The ability of arbitrage to equate asset prices or rates of return across countries has been widely tested. One would expect that in the absence of barriers to cross-border financial flows, arbitrage would bring interest rates into equality. But the answer depends on the precise condition tested. Interest rates that have had the element of exchange risk removed by forward market cover are indeed virtually equated across national borders among industrialized countries, showing that they have few controls on international capital movements. But interest rates seem not to be equalized across countries when adjusted for expectations of exchange rate changes rather than for

\footnotetext{
18 Taylor (1996).

${ }^{19}$ Frankel (1992) is a short survey of the saving-investment and interest parity tests of financial integration.
} 
forward exchange rates, and interest rates are definitely not equalized when adjusted for expected inflation rates. Evidently currency differences are important enough to drive a wedge between expected rates of return. Furthermore, residual transactions costs or imperfect information apparently affect cross-border investment in equities. ${ }^{21}$ They discourage investors altogether from investing in some information-intensive assets, such as mortgages, across national borders. Furthermore, country risk still adds a substantial penalty wedge to all investments in developing countries.

In short, though international financial markets, much like goods markets, have become far more integrated in recent decades, they have traversed less of the distance to perfect integration than is widely believed. Globalization is neither new, nor complete, nor irreversible.

\section{The Impact of Economic Globalization}

We turn now from documenting the extent of globalization, and its sources, to considering the effects of globalization, and its merits. We must acknowledge a lower degree of certainty in our answers. It becomes harder to isolate cause and effect.

\footnotetext{
${ }^{20}$ Lewis (1995).

${ }^{21}$ Country-specific sentiment seems to separate investors who reside in different countries. The price of a closed-end country fund traded in New York City differs widely from the "net asset value," the price of the basket of stocks traded in the country, which should be identical in value. Even in the case of what is virtually the identical company, Froot and Dabora (1999) show that Siamese twins like Royal Dutch/Shell exhibit imperfect integration, the price of Royal Dutch behaving as if it is part of the New York
} 
Moreover, once we extend the list of objectives beyond maximizing national incomes measured in marketplace dollars, value judgments come into play. Nevertheless, economic theory and empirical research still have much to contribute.

\section{The Effect of Trade on the Level and Growth of Real Income}

Why do economists consider economic integration so important? What are the benefits of free trade for the economy?

\section{The theoretical case for trade}

Classical economic theory tells us that there are national gains from trade, associated with the phrase comparative advantage. Over the last two decades, scholars have developed a "New Trade Theory;" it suggests the existence of additional benefits from trade, which are termed dynamic. We consider each theory in turn.

The classical theory goes back to Adam Smith and David Ricardo. Adam Smith argued that specialization--the division of labor--enhances productivity. David Ricardo extended this concept to trade between countries. The notion is that trade allows each country to specialize in what it does best, thus maximizing the value of its output. If a government restricts trade, resources are wasted in the production of goods that could be imported more cheaply than they can be produced domestically.

What if one country is better than anyone else at producing every good? The argument in favor of free trade still carries the day. All that is required is for a country to

stock market and Shell as part of the London market. 
be relatively less skilled than another in the production of some good in order for it to benefit from trade. This is the doctrine of comparative advantage--the fundamental (if perhaps counterintuitive) principle that underlies the theory of international trade. It makes sense for Michael Jordan to pay someone else to mow his lawn, even if Jordan could do it better himself, because he has a comparative advantage at basketball over lawnmowing. Similarly, it makes sense for the United States to pay to import certain goods that can be produced more efficiently abroad (apparel, shoes, tropical agriculture, consumer electronics), because the US has a comparative advantage in other goods (aircraft, financial services, wheat and computer software).

This is the classical view of the benefits of free trade in a nutshell. Two key attributes of the classical theory are worth flagging. First, it assumes perfect competition, constant returns to scale, and fixed technology, assumptions that are not very realistic. Second, the gains from trade are primarily static in nature--that is, they affect the level of real income. The elimination of trade barriers raises income, but this is more along the lines of a one-time increase.

What of the "New Trade Theory?" It is more realistic than the classical theory, in that it takes into account imperfect competition, increasing returns to scale, and changing technology. It can be viewed as providing equally strong, or stronger, support for the sort of free-trade policies that the U.S. has followed throughout the post-war period, that is, multilateral and bilateral negotiations to reduce trade barriers, than did the classical theory. ${ }^{22}$

${ }^{22}$ Grossman and Helpman (1991) and Helpman and Krugman (1985). 
To be sure, these theories say that, under certain very special conditions, one country can get ahead by interventions (e.g., subsidies to strategic sectors), provided the government gets it exactly right, and provided the actions of other countries are taken as given. But these theories also tend to have the property that a world in which everyone is subsidizing at once is a world in which everyone is worse off, and that we are all better off if we can agree to limit subsidies or other interventions.

Bilateral or multilateral agreements where other sides make concessions to US products, in return for whatever concessions we make, are virtually the only sorts of trade agreements we have made. Indeed, most recent trade agreements (like NAFTA and China's accession to the WTO) have featured much larger reductions in import barriers on the part of our trading partners than we are required to make ourselves. The reason for this is that their barriers were higher than ours to start with. But the natural implication is that such agreements raise foreign demand for our products by more than they raise our demand for imports. Hence we are likely to benefit from a positive "terms of trade effect." This just adds to the usual benefits of increased efficiency of production and gains to consumers from international trade.

Furthermore, even when a government does not fear retaliation from abroad for trade barriers, intervention in practice is usually based on inadequate knowledge and is corrupted by interest groups. Seeking to rule out all sector-specific intervention is the most effective way of discouraging rent-seeking behavior. Globalization increases the number of competitors operating in the economy. Not only does this work to reduce distortionary monopoly power in the marketplace (which is otherwise exercised by 
raising prices); it can also reduce distortionary corporate power in the political arena (which is exercised by lobbying).

Most importantly, new trade theory offers reason to believe that openness can have a permanent effect on a country's rate of growth, not just the level of real GDP. A high rate of economic interaction with the rest of the world speeds the absorption of frontier technologies and global management best practices, spurs innovation and costcutting, and competes away monopoly.

These dynamic gains come from a number of sources. They included the benefits of greater market size and enhanced competition. Other sources include technological improvements through increased contact with foreigners and their alternative production styles. Such contact can come, for example, from direct investment by foreign firms with proprietary knowledge, or by the exposure to imported goods that embody technologies developed abroad. Each of these elements of international trade and interactions has the effect of promoting growth in the domestic economy. When combined with the static effects, there is no question that the efforts to open markets, when successful, can yield significant dividends.

\section{The empirical case for trade}

Citing theory is not a complete answer to the question, "How do we know that trade is good?" We need empirical evidence. Economists have undertaken statistical tests of the determinants of countries' growth rates. Investment in physical capital and investment in human capital are the two factors that emerge the most strongly. But other factors matter as well. Estimates of growth equations have found a role for openness, 
measured for example as the sum of exports and imports as a share of GDP. Frankel and Romer (1999) looked at a cross-section of 100 countries during the period since 1960. We sought to address a major concern regarding simultaneous causality between growth and trade: Does openness lead to growth, or does growth lead to openness? We found that the effect of openness on growth is even stronger when we correct for the simultaneity, as compared with standard estimates.

The estimate of the effect of openness on income per capita ranges from 0.3 to 3.0. ${ }^{23}$ Consider a round middle number such as 1.0. The increase in U.S. openness since the 1950 s is .12. Multiplying the two numbers together implies that the increased integration has had an effect of 12 percent on U.S. income. More dramatically, compare a stylized Burma, with a ratio close to zero, versus a stylized Singapore, with a ratio close to $100 \%$. Our ball-park estimate, the coefficient of 1.0, implies that Singapore's income is $100 \%$ higher than Burma's as a result of its openness. The fact that trade can affect a country's growth rate--as opposed to affecting the level of its GDP in a "one-shot" fashion--makes the case for trade liberalization even more compelling.

One possible response is that this approach demonstrates only the growth benefits from geographically-induced trade, and need not necessarily extend to the effects of policy-induced trade. ${ }^{24}$ But popular critics of globalization seem to think that increased international trade and finance is the problem, regardless whether it comes from

\footnotetext{
${ }^{23}$ The smaller estimate is the more relevant if one wishes to hold constant for such income determinants as investment, human capital, and initial (1960) income, in order to isolate the direct medium-run effect of trade on income. But given the estimated speed of convergence, an effect of .3 over a 25-year period translates into an effect of 1.2 in the long-run steady state. Irwin and Tervio (2000), going back as far as 1913, find large effects as well.

${ }^{24}$ Rodrik and Rodriguez (2000) have critiqued the empirical literature that finds an
} 
technological progress or government liberalization. As the critics make their arguments against government dismantling of policy barriers, they seldom stipulate that cross-border interactions attributable to geography or to technological innovations in transport are economically beneficial.

\section{Macroeconomic interdependence.}

Trade and financial integration generally increase the transmission of business cycle fluctuations among countries. Floating exchange rates give countries some insulation against each other's fluctuations. When capital markets are highly integrated, floating rates do not give complete insulation, as the post-1973 correlation among major industrialized economy shows. But international transmission can be good for a country as easily as bad, as happens when adverse domestic developments are in part passed off to the rest of the world. The trade balance can act as an important automatic stabilizer for output and employment, improving in recessions and worsening in booms.

Contagion of financial crises is more worrying. The decade of the 1990s alone abounds with examples: the 1992-93 crises in the European Exchange Rate Mechanism, the "tequila crisis" that began with the December 1994 devaluation of the Mexican peso, and the crises in East Asia and emerging markets world-wide from July 1997 to January 1999. Evidently when one country has a crisis it affects others. There is now a greater consensus among economists than before that not all of the observed volatility, or its cross-country correlation, can be attributed to efficient capital markets punishing or rewarding countries based on a rational evaluation of the economic fundamentals. It is difficult to do justice in one paragraph to a discussion that is as voluminous and vigorous

association between trade and growth. 
as the debate over the welfare implications of the large increase in international capital flows. Still, the majority view remains that countries are overall better off with modern globalized financial markets than without them. ${ }^{25}$

\section{The Effect of Trade on Other Social Goals}

Many who fear globalization concede that trade has a positive effect on aggregate national income, but suspect that it has adverse effects on other highly-valued goals such as labor rights, food safety, culture, and so forth. Here we consider only two major values - equality and the environment -- and briefly at that. ${ }^{26}$

\section{Income distribution}

International trade and investment can be a powerful source of growth in poor countries, helping them catch up with those who are ahead in endowments of capital and technology. This was an important component of the spectacular growth of East Asian countries between the 1960s and the 1990s, which remains a miracle even in the aftermath of the 1997-98 currency crises. By promoting convergence, trade can help reduce the enormous worldwide inequality in income. Most of those who are concerned

\footnotetext{
${ }^{25}$ There are many possible references. Obstfeld (1998) and Frankel (1999) each succinctly state the arguments for and against international capital mobility.

${ }^{26}$ One of the most important arguments in favor of trade is also non-economic - that it promotes peace and understanding, and helps spread values like democracy and free markets that Americans prize. There is not space to discuss this argument here. This is probably just as well, as many opponents are under the illusion that free trade is a favor that Americans do to benefit other countries - a favor, for example, that was geopolitically necessary during the Cold War but that we can no longer afford.
} 
about income distribution, however, appear to be more motivated by within-country equality than global equality.

A standard textbook theory of international trade, the Heckscher-OhlinSamuelson model, has a striking prediction to make regarding within-country income distribution. It is that the scarce factors of production will lose from trade and the abundant factors will benefit. This means that in rich countries, those who have capital and skills will benefit at the expense of unskilled labor, whereas in poor countries it will be the other way around. The same prediction holds for international capital mobility (or, for that matter, for international labor mobility). It has been very difficult, however, to find substantial direct evidence of the predictions of the model during the post-war period, including distribution effects within either rich or poor countries. Most likely the phenomena of changing technology, intra-industry trade, and worker ties to specific industries, are more important today than the factor endowments at the heart of the Hecksher-Ohlin-Samuelson model. ${ }^{27}$

In the United States, the gap between wages paid to skilled workers and wages paid to unskilled workers rose by 18 percentage points between 1973 and 1995, and then leveled off. The fear is that trade is responsible for some of the gap, by benefiting skilled workers more than unskilled workers. Common statistical estimates - which typically impose the theoretical framework rather than testing it -- are that between 5 and $30 \%$ of the increase is attributable to trade. Technology, raising the demand for skilled workers faster than the supply, is the major factor responsible for the rest (e.g., Krugman and

${ }^{27}$ O'Rourke and Williamson (1999) find that trade did have the major equalizing influence hypothesized on returns to labor, land, and capital in the $19^{\text {th }}$ century, the period that the Heckscher-Ohlin theory was designed to explain. 
Lawrence, 1994). One of the higher estimates is that trade contributes one third of the net increase in the wage gap. ${ }^{28}$

On a sample of 73 countries, Chakrabarti (2000) finds that trade actually reduces inequality, as measured by the Gini coefficient. This relationship also holds for each income class.

It is clear that income distribution is determined by many factors beyond trade. One is redistribution policies undertaken by the government. In some cases such policies are initiated in an effort to compensate or "buy off" groups thought to be adversely affected by trade. But a far more important phenomenon is the tendency for countries to implement greater redistribution as they grow richer.

A long-established empirical regularity is the tendency for income inequality to worsen at early stages of growth, and then to improve at later stages. The original explanation for this phenomenon, known as the Kuznets curve, had to do with rural-urban migration. ${ }^{29}$ But a common modern interpretation is that income redistribution is a "superior good" - something that societies choose to purchase more of, even though at some cost to aggregate income, as they grow rich enough to be able to afford to do so. If this is right, then trade can be expected eventually to raise equality, by raising aggregate income.

\footnotetext{
${ }^{28}$ Though this is only 6 percent of the total unequalizing forces. The complication is that there has been a large increase in the supply of skilled workers, which works to drive down their relative wage; thus the total unequalizing forces to be explained is more than $100 \%$ of the increase in the gap between skilled and unskilled wages. Cline (1997).

${ }^{29}$ Barro (1999) includes references, and updated statistical support for the relationship for many countries.
} 


\section{Environment}

Similar logic holds that trade and growth can also good for the environment, once the country gets past a certain level of per capita income. Grossman and Krueger (1993, 1995) found what is called the environmental Kuznets curve: growth is bad for air and water pollution at the initial stages of industrialization, but later on reduces pollution, as countries become rich enough to pay to clean up their environments. A substantial literature has followed. ${ }^{30}$ A key point is that popular desires need not translate automatically into environmental quality; rather government intervention is usually required to address externalities.

The idea that trade can be good for environment is surprising to many. The pollution-haven hypothesis instead holds that trade encourages firms to locate production of highly polluting sectors in low-regulation countries, in order to stay competitive. But economists' research suggests that environmental regulation is not a major determinant of firms' ability to compete internationally. ${ }^{31}$ Furthermore, running counter to fears of a "race to the bottom," is the Pareto-improvement point: trade allows countries to attain more of whatever their goals are, including higher market-measured income for a given level of environmental quality or a better environment for a given level of income. In a model that combines various effects of trade, including via the scale and composition of output, Antweiler, Copeland and Taylor (1998) estimate that if openness raises GDP by 1

\footnotetext{
${ }^{30}$ Harbaugh, Levinson and Wilson (2000) find that some revised data are not as supportive of the inverted U-shaped relationship between income and pollution. But they also find that trade per se has a beneficial effect, holding constant for income. ${ }^{31}$ When deciding where to locate, multinational firms pay far more attention to such issues as labor costs and market access than to the stringency of local environmental regulation. Tobey (1990) and Jaffe, Peterson, Portney and Stavins (1995).
} 
percent, then it reduces sulphur dioxide concentrations by 1 per cent. The implication is that, because trade is good for growth, it is also good for the environment.

The econometric studies of the effects of trade and growth on the environment get different results depending on what measures of pollution they use. There is a need to look at other environmental criteria as well. It is difficult to imagine, for example, that trade is anything but bad for the survival of tropical hardwood forests or endangered species, absent substantial efforts by governments to protect them.

The argument that richer countries will take steps to clean up their environments holds only for issues where the effects are felt domestically -- where the primary "bads," such as smog or water pollution, are external to the firm or household, but internal to the country. Some environmental externalities that have received increased attention in recent decades, however, are global. Biodiversity, overfishing, depletion of stratospheric ozone, and greenhouse gas emissions are four good examples. A ton of carbon dioxide has the same global warming effect regardless where in the world it is emitted. In these cases, individual nations can do little to improve the environment on their own, no matter how concerned are their populations or how effective their governments. For each of the four examples, governments have negotiated international treaties in an attempt to deal with the problem. But only the attempt to address ozone depletion, the Montreal Protocol, can be said as yet to have met with much success.

Is the popular impression then correct, that international trade and finance exacerbates these global environmental externalities? Yes, perhaps, but only in the sense that trade and finance promote economic growth. Clearly if mankind were still a population of a few million people living in pre-industrial poverty, greenhouse gas 
emissions would not be a big issue. Industrialization leads to environmental degradation, and trade is part of industrialization. But virtually everyone wants industrialization, at least for themselves. Deliberate self-impoverishment is not a promising option. Once this point is recognized, there is nothing special about trade, as compared to the other sources of economic growth: capital accumulation, rural-urban migration, and technological progress.

US congressional opponents of the Kyoto Protocol fear that if the industrialized countries agreed to limit emissions of carbon dioxide and other greenhouse gases, there would be an adverse effect on American economic competitiveness vis-à-vis the developing countries, who are not yet covered by the treaty. This is partially true: those US sectors that are highly carbon-intensive, such as aluminum smelting, would indeed suffer adversely. But other US sectors would be favorably affected by trade with nonparticipating countries. The real issue -- the true reason why we need the developing countries to participate in a global climate change agreement -- is that the industrialized countries would otherwise have very little effect on aggregate global emissions over the coming decades, even if they were willing to cooperate and to bear moderately high costs involved in restructuring their energy economies. But this point has nothing to do with trade. It would be the same in a world without economic globalization.

\section{Summary of Conclusions}


This chapter was able to give confident answers to questions about the extent and sources of economic globalization, and moderately confident answers to some questions about its effects.

The world has become increasingly integrated with respect to trade and finance since the end of World War II, due to declining costs to transportation and communication and declining government barriers. The phenomenon is neither new nor complete, however. In the first regard, globalization was more dramatic in the halfcentury preceding the first World War, and much of the progress during the last halfcentury has merely reversed the closing-off that came in between. In the second regard, globalization is far from complete. Contrary to popular impressions, national borders and geography still impede trade and investment substantially. A simple calculation suggests that the ratio of trade to output would have to increase at least another six-fold before it would be true that Americans trade across the globe as readily as across the country. Such barriers as differences in currencies, languages, political systems, each have their own statistically-estimated trade-impeding influences, besides the remaining significant effects of distance, borders, and other geographical and trade-policy variables.

The chapter's discussion of the impacts of economic globalization has necessarily been exceedingly brief. Both theory and evidence are read as clearly supportive of the proposition that trade has a positive effect on real incomes. This is why economists believe it is important that the process of international integration be allowed to continue, especially for the sake of those countries that are still poor.

Effects on social values other than aggregate incomes can be either positive or negative, depending on the details, and the statistical evidence does not always give 
clear-cut answers about the bottom line. In the two most-studied cases, income distribution and environmental pollution, there seems to be a pattern whereby things get worse in the early stages of industrialization, but then start to get better at higher levels of income. Societies that become rich in terms of market-measured output choose to improve their quality of life in other ways as well. It is possible that the same principle extends to non-economic values such as safety, human rights and democracy. In short, there is reason to hope that, aside from the various more direct effects of trade on noneconomic values, there is a general indirect beneficial effect that comes via the positive effect of trade on income.

\section{Whereto Now, in the Wake of Seattle?}

Questions of international governance lie outside the scope of this chapter. But I will conclude with an observation regarding the subject of labor and environmental standards, which inspired fervent demonstrations at the November 1999 WTO meeting in Seattle. An International Trilemma composed of sovereignty, regulation, and integration has been noted: countries can have any two of these three desirable goals, but they cannot have all three at once. Does this mean that globalization impedes sovereign countries from choosing their own labor and environmental regulations? Perhaps. But such crossborder concerns as child labor, endangerment of species, and emissions of greenhouse gases do not arise from international trade and investment. These problems would exist even without trade. The concerns arise from a non-economic kind of globalization having more to do with the transmission of information and ideas -- considered in other 
chapters of this volume. Presumably the demonstrators do not favor shutting off this transmission. But in that case shutting off economic globalization would not help either. Neither international trade nor global institutions such as the WTO are obstacles to addressing those concerns. To the contrary, the obstacle to multilateral efforts to protect the global environment, such as ratification of the Kyoto Protocol on Climate Change, is precisely national sovereignty, along with a failure of citizens of each country to agree among themselves on the priority that their society should place on environmental benefits. These two obstacles -- obsession with national sovereignty and internal disagreements -- are, ironically, as bad or worse in the United States as in other countries. The obstacle to international action on the environment is not, as most of the Seattle demonstrators appeared to believe, the infringement of sovereignty by multilateral institutions such as the WTO. 


\section{References}

Alesina, Alberto, Enrico Spolaore and Romain Wacziarg, 1999, "Economic Integration and Political Disintegration," December.

Antweiler, Werner, Brian Copeland, and M. Scott Taylor, 1998, "Is Free Trade Good for the Environment?” NBER Working Paper No. 6707, August.

Baldwin, Richard, and Philippe Martin, 1999, "Two Waves of Globalization: Superficial Similarities, Fundamental Differences,” NBER Working Paper No. 6904, January.

Barro, Robert, 1999, “Inequality, Growth, and Investment,” NBER Working Paper No. 7038, March.

Bordo, Michael, Barry Eichengreen and Douglas Irwin, 1999, "Is Globalization Today Really Different Than Globalization a Hundred Years Ago?" Brookings Trade Forum 1999.

Chakrabarti, Avik, 2000, "Do Nations that Trade More Have a More Unequal Distribution of Income?" University of Wisconsin, Milwaukee.

Cline, William, 1997, Trade, Jobs, and Income Distribution, Institute for International Economics, Washington, DC.

Drysdale, Peter, and Ross Garnaut. 1982, "Trade Intensities and the Analysis of Bilateral Trade Flows in a Many-Country World," Hitotsubashi Journal of Economics 22, 62-84.

Engel, Charles, 1993, "Real Exchange Rates and Relative Prices: An Empirical Investigation," Journal of Monetary Economics 32, August, 35-50.

Engel, Charles, and John Rogers, "How Wide is the Border?" American Economic Review 86, no.5, December 1996, 1112-1125.

Feldstein, Martin and Charles Horioka, 1980, "Domestic Saving and International Capital Flows," Economic Journal 90: 314-29.

Frankel, Jeffrey, "Measuring International Capital Mobility: A Review," American Economic Review 82, no.2 (May 1992), 197-202.

Frankel, Jeffrey, Regional Trading Blocs in the World Trading System, Institute for International Economics, Washington DC, 1997.

Frankel, Jeffrey, 1999, "Proposals Regarding Restrictions on Capital Flows," African Finance Journal vol.1, part 1. 
Frankel, Jeffrey and David Romer, 1999, "Does Trade Cause Growth?" American Economic Review, June.

Frankel, Jeffrey and Andrew Rose, 2000, “An Estimate of the Effect of Currency Unions on Trade and Growth," Alesina-Barro conference, Stanford University.

Frankel, Jeffrey and Shang-Jin Wei, "Regionalization of World Trade and Currencies: Economics and Politics" in The Regionalization of the World Economy, J. Frankel, editor, University of Chicago Press, Chicago, 1997.

Froot, Kenneth, and Emil Dabora, 1999, "How Are Stock Prices Affected by the Location of Trade," Journal of Financial Economics 53, August, 182-216.

Froot, Kenneth, Michael Kim, and Kenneth Rogoff, "The Law of One Price Over 700 Years,” NBER Working Paper No. 5132, May 1995.

Gowa, Joanne, and Edward Mansfield, 1993, "Power Politics and International Trade," American Political Science Review 87, no. 2, June, 408-420.

Grossman, Gene, and Elhanan Helpman, 1991, Innovation and Growth in the Global Economy, MIT Press: Cambridge.

Grossman, Gene, and Alan Krueger, 1993, "Environmental Impacts of a North American Free Trade Agreement," in The U.S.-Mexico Free Trade Agreement, Peter Garber, ed., Cambridge MA, MIT Press.

Grossman, Gene, and Alan Krueger, 1995, "Economic Growth and the Environment," Quarterly Journal of Economics, 353-377.

Harbaugh, William, Arik Levinsohn, and David Wilson, 2000, "Reexamining the Empirical Evidence for an Environmental Kuznets Curve," NBER Working Paper No. 7711, May.

Helliwell, John, 1998, How Much Do National Borders Matter? Brookings Institution: Washington DC.

Helliwell, John, and John McCallum. 1995. "National Borders Still Matter for Trade." Policy Options/Options Politiques 16, July/August: 44-48.

Helpman, Elhanan and Paul Krugman. 1985. Market Structure and Foreign Trade, Cambridge, MIT Press.

Irwin, Douglas, and Marko Tervio, 2000, "Does Trade Raise Income? Evidence from the Twentieth Century," preliminary draft, March. 
Jaffe, Adam, S. Peterson, Paul Portney and Robert Stavins, 1995, “Environmental Regulation and the Competitiveness of U.S. Manufacturing: What Does the Evidence Tell Us?" Journal of Economic Literature 33, 132-163.

Keynes, John Maynard, 1920, The Economic Consequences of the Peace, Harcourt Brace, and Howe: New York.

Kleiman, Ephraim, 1976, "Trade and the Decline of Colonialism," The Economic Journal 86, September, 459-480.

Krugman, Paul, 1995, “Growing World Trade:Causes and Consequencers," Brookings Papers on Economic Activity no. 1, 327-362.

Krugman, Paul, aand Robert Lawrence, 1994, "Trade, Jobs and Wages," Scientific American, April.

Lewis, Karen, "Puzzles in International Financial Markets," in Handbook of International Economics, vol. 3, edited by Gene Grossman and Kenneth Rogoff, North Holland, 1995.

Linnemann, Hans. 1966. An Econometric Study of International Trade Flows, NorthHolland, Amsterdam.

Mansfield, Edward, 1993, "Effects of International Politics on Regionalism in International Trade," in Kym Anderson and Richard Blackhurst, eds., Regional Integration and the Global Trading System, Harvester Wheatsheaf.

Mansfield, Edward, and Rachel Bronson, 1997, "The Political Economy of Major-Power Trade Flows," in Edward Mansfield and Helen Milner, eds., The Political Economy of Regionalism, New York: Columbia University Press.

McCallum, John, 1995, "National Borders Matter: Canada-U.S. Regional Trade Patterns," American Economic Review 85, no.3, June, 615-623.

Obstfeld, Maurice, 1998, “The Global Capital Market: Benefactor or Menace?” NBER Working Paper No. 6559, May. Forthcoming, Journal of Economic Perspectives.

O'Rourke, Kevin, and Jeffrey Williamson, 1999, “The Heckscher-Ohlin Model Between 1400 and 2000 Whe it Explained Factor Price Convergence, When It Did Not, and Why," NBER Working Paper No. 7411, November.

Pritchett, Lant, and Geeta Sethi, 1994, "Tariff Rates, Tariff Revenue and Tariff Reform: Some New Facts," World Bank Economic Review 8, no. 1, January: 1-16.

Rodrik, Dani, and Francisco Rodríguez, 1999, "Trade Policy and Economic Growth: A Skeptic's Guide to the Cross-National Evidence," Kennedy School of Government, Harvard University, April. 
Rogoff, Kenneth, 1996, “The purchasing power parity puzzle," Journal of Economic Literature, 34: (2), June, 647-668 .

Rose, Andrew, 2000, "One Money, One Market: Estimating the Effect of Common Currencies on Trade," Economic Policy, 30, April, 7-46.

Taylor, Alan, 1996, "International Capital Mobility in History: The Saving-Investment Relationship," NBER Working Paper 5743.

Tobey, J.A., 1990, "The Effects of Domestic Environmental Policies on Patterns of World Trade: An Empirical Test,” Kyklos 43, 191-209.

Wei, Shang-Jin. 1996. "How Stubborn Are Nation States in Globalization?" NBER Working Paper 5331. April. 